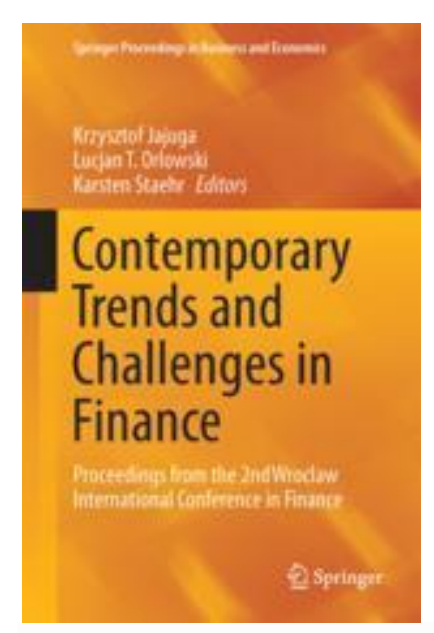

Contemporary Trends and Challenges in Finance pp 145-153

\title{
The Quality of Financial Information and Stock Market Development: A Panel Data Study for the European Economies
}

Authors

Darko Lazarov

Tanja Lakovic

Emilija Miteva Kacarski

Conference paper

First Online:

02 May 2017

DOI: 10.1007/978-3-319-54885-2_14

Part of the Springer Proceedings in Business and Economics book series (SPBE) Cite this paper as:

Lazarov D., Lakovic T., Miteva Kacarski E. (2017) The Quality of Financial Information and Stock Market Development: A Panel Data Study for the European Economies. In: Jajuga K., Orlowski L., Staehr K. (eds)

Contemporary Trends and Challenges in Finance. Springer Proceedings in Business and Economics. Springer, Cham

\section{Abstract}

The main aim of the paper is to investigate whether the quality of financial information facilitates and promotes the stock market development. We test this hypothesis by using a sample of 36 European economies in the period 2006-2012 based on dynamic panel regression (system GMM) approach. The strength of auditing and reporting standards (SARS) is used as a measure of financial information quality, while the stock market capitalization relative to GDP measures the stock market development. The estimated results demonstrate positive and 
significant relationship between financial information quality and capital market development after controlling for the standard macroeconomic and financial specific stock market determinants, suggesting that financial reporting quality is one of the most important determinants of stock market development in European economies. The effects of financial reporting to stock market development are much more significant in the case of non-EU countries. Additionally, the results suggest that growth rate, foreign direct investment, banking sector and corporate governance quality are positively and significantly associated with stock market development, while inflation rate and stock price volatility as measures of macroeconomic and stock price instability have negative influence on stock market activity.

\section{References}

1. Arrelano M, Bover O (1995) Another look at the instrumental-variable estimation of error-components models. J Econ 68:29-52CrossRefGoogle Scholar

2. Arrelano M, Bond S (1991) Some tests of specification for panel data: Monte Carlo evidence and an application to employment equations. Rev Econ Stud 58:277297CrossRefGoogle Scholar

3. Ball R (2006) International financial reporting standards (IFAC): pros and cons for investors. Account Bus Res Int Account Policy Forum 36(1):5-27 Google Scholar

4. Barht EM, Landsman RW, Lang HM (2008) International accounting standards and accounting quality. J Account Res 46(3):467-498당ssefGoogle Scholar

5. Blundell R, Bond S (1998) Initial conditions and moment restrictions in dynamic panel data models. J Econ 87:115-143

6. Chen S, Sun Z, Wang Y (2002) Evidence from China on whether harmonized accounting standard harmonize accounting practice. Account Horiz 16(3):183197CrossRefGoogle Scholar

7. Christensen H, Hail L, Leuz C (2013) Mandatory IFRS reporting and changes in enforcement. J Account Econ 56:147-177ㄷosRefGoogle Scholar

8. Daske H, Hail L, Leuz C, Verdi R (2008) Mandatory IFRS reporting around the world: early evidence on the economic consequences. J Account Res 46:10851142Google Scholar

9. Djankov S, McLiesh C, Shleifer A (2007) Private credit in 129 countries. J Financ Econ 84(2):299-329 CrossRefGoogle Scholar

10. European Commission (2015) Report from the Commission to the European Parliament and the Council: Evaluation of Regulation (EC) $\mathrm{N}^{\circ} 1606 / 2002$ of $19 \mathrm{July}$ 2002 on the application of International Accounting StandardsGoogle Scholar

11. Garcia FV, Liu L (1999) Macroeconomic determinants of stock market development. J Appl Econ 2(1):29-59Google Scholar 
12. Friedman LH (2015) Capital market development, the strength of financial reporting standards and

trust. http://papers.ssrn.com/sol3/papers.cfm?abstract id=2587403. Accessed 10 Jun 2016

13. Jara E, Ebrero A, Zapata R (2011) Effect of international financial reporting standards on financial information quality. J Financ Report Account 9(2):176196ㄷossRefGoogle Scholar

14. La Porta R, Lopez-de-Silanes F, Shleifer A (1997) Legal determinants of external finance. J Financ 52:113-150Google Scholar

15. La Porta R, Lopez-de-Silanes F, Shleifer A (2008) The economic consequences of legal origins. J Econ Lit 46(2):285-332CrossRefGoogle Scholar

16. Windmeijer F (2005) A finite sample correction for the variance of linear efficient two-step GMM estimators. J Econ 126:25-51rossRefGoogle Scholar

17. World Bank. The Global Financial Development

Database. http://data.worldbank.org/data-catalog/global-financial-development. Accessed 10 Feb 2016

18. World Bank. World Development Indicators

Database. http://data.worldbank.org/indicator. Accessed 10 Feb 2016

19. Wulandari RE, Rahman RA (2004) A cross-country study on the quality, acceptibility and enforceability of accounting standards and the value relevance of accounting earnings. http://www.oecd.org/finance/financialmarkets/33735584.pdf. Accessed 5 Jun 2016

\section{Copyright information}

(C) Springer International Publishing AG 2017

\section{About this paper}

- Publisher NameSpringer, Cham

- Print ISBN978-3-319-54884-5

- Online ISBN978-3-319-54885-2

- eBook PackagesEconomics and Finance

- About this book

- Reprints and Permissions

Log in to check access

Buy eBook

EUR 166.59

Buy paper (PDF)

EUR 24.95

- Instant download 
- Readable on all devices

- Own it forever

- Local sales tax included if applicable

Learn about institutional subscriptions

Export citation

- .RISPapersReference ManagerRefWorksZotero

- .ENWEndNote

- .BIBBibTeXJabRefMendeley

Share paper

- Email

- $\quad$ Facebook

- Twitter

- LinkedIn

We use cookies to improve your experience with our site. More information Accept

Over 10 million scientific documents at your fingertips

Academic Edition

- Corporate Edition

- Home

- Impressum

- Legal Information

- Accessibility

- Contact Us

(C) 2017 Springer International Publishing AG. Part of Springer Nature.

Not logged in Not affiliated 46.217.58.16 